\title{
A SZOCIÁLIS KOMPETENCIA FEJLŐDÉSE A HÁTRÁNYOS HELYZETÚ GYEREKEKNÉL
}

\section{Szerzők:}

Bagány Ágnes

Újvidéki Egyetem (Szerbia)

Major Lenke

Újvidéki Egyetem (Szerbia)

Josip Lepeš

Újvidéki Egyetem (Szerbia)

Első szerző e-mail címe:

agnes.torteli@magister.uns.ac.rs
Lektorok:

Horák Rita

Újvidéki Egyetem (Szerbia)

Pintér Krekity Valéria

Újvidéki Egyetem (Szerbia)

Schéder Veronika

Debreceni Egyetem

Mező Katalin

Debreceni Egyetem

Bagány Ágnes, Major Lenke és Lepeš, Josip (2015): A szociális kompetencia fejlődése a hátrányos helyzetü gyerekeknél. Különleges Bánásmód, I. évf. 2015/1. szám, 87-94. DOI 10.18458/KB.2015.2.87

\begin{abstract}
Absztrakt
2010 szeptemberében az oktatási reformmal, vagyis az inklúzió bevezetésével Szerbiában ugrásszerüen megnött a hátrányos helyzetü és halmozottan hátrányos helyzetü gyerekek beiskolázása. 2013 szeptemberétől az Újvidéki Egyetem Magyar Tannyelvü Tanítóképzö Kara és a Szegedi Tudományegyetem Juhász Gyula Pedagógusképzö Kar Felnöttképzési Intézete egy közös projekt keretén belül kidolgozott egy programot, ahol a két intézmény hallgatói mentorokként vettek részt a hátrányos helyzetü gyerekek felzárkóztatásában. Tanulmányunk célja bemutatni a Hallgatói Mentorprogram felépítését, amely jó gyakorlatul szolgálhat hasonló problémákkal küzdö iskolák számára. A gyakorló pedagógusok véleménye alapján a mentorprogram hosszú távú hatásaként kiemelnénk a mentorált tanulók szociális kompetenciáinak fejlödését.
\end{abstract}

Kulcsszavak: hátrányos helyzet, mentorprogram, felzárkóztatás, szociális kompetencia

Diszciplínák: pedagógia, gyógypedagógia, pszichológia

\footnotetext{
Abstract

DEVELOPMENT OF THE SOCIAL COMPETENCE OF CHILDREN FROM AN UNDERPRIVILEGED BACKGROUND

In September, 2010, by the introduction of the educational reform in Serbia, namely the introduction of inclusion, the number of children from a disadvantaged background and multiple disadvantaged background has significantly increased. From September 2013, the University of Novi Sad, Faculty of Education in Hungarian Language, Subotica and
} 
University of Szeged, Gyula Juhász Faculty of Education, Institute of Adult Education worked out a programme, in which the students of these two Universities participated as mentors in the compensatory education of disadvantaged children. The purpose of the present study is to introduce the structure of the Student Mentoring Program that serves as an excellent example for other schools. According to in-service teachers, one of the long-term positive outcomes of the mentoring program is the development of social competences of disadvantaged children.

Keywords: disadvantageous background, mentoring program, compensatory education, social competence

Disciplines: pedagogy, special education, psychology

\section{Inklúzió és a szociális kompetencia}

Az inklúzió - mint az exklúzió, a kirekesztés ellentétes irányú folyamata - elősegíti az eredményesség növelését, ha meghatározó formává válik a különböző képzési formákban, közösségekben. Alapvető célja, hogy eszközrendszerével csökkentse a kizárásra irányuló nyomást az iskolában és a társadalomban. Az inklúzió azt jelenti, hogy az egyes kultúrákhoz és közösségekhez tartozók befogadása soha be nem fejeződő folyamat, állandó munka egy ideálért, amikor a társadalomban tapasztalható kizárási kényszerek eltünnek. A befogadó iskola a közösség oktatásának a forrása, és maga az oktatás több mint az iskoláztatás cselekvés a közösséggel, a közösségben, a közösségért (Kalocsainé és Varga, 1995).

Az új szerbiai oktatási kerettörvény szövegéből a nem jogvégzett ember is ki tudta olvasni, hogy a kötelező beiskolázás terén 2010 szeptemberében jelentős változások léptek hatályba. A beiratkozás korhatárát már korábban is egy fél évvel előbbre tették, hét esztendő helyett hat és fél éves korában minden gyermeknek az iskolapadban van a helye. Eddig az iskolaelőkészítő folyamat során külön-külön vizsgálták minden egyes tanuló pszichofizikai és szociális érettségét, s ennek alapján esetleg későbbre lehetett halasztani az elsőbe indulást. Ha pedig ezt egy erre szakosodott komoly bizottság (melyben gyermekgyógyász, pszichiáter, pszichológus, defektológus és szociális gondozó is helyet kapott) jónak látta, kisegítő tagozatba vagy a különleges igényekkel élő gyermekek oktatására és nevelésére szakmai és tárgyi szempontból felkészült szakintézményekbe utalta (Törteli, 2014).

Az egymástól eltérő családi hátterü, hátrányos szociális vagy gazdasági helyzetü tanulók inkluzív oktatása nagy nehézségekbe ütközött az új oktatási politika bevezetésével. A kérdés az, hogy a különbözö hátterü gyermekeket együtt vagy külön érdemes-e oktatni, milyen módszereket érdemes alkalmazni, és mindez milyen hatással lehet a roma és nem roma, hátrányos helyzetü és nem hátrányos helyzetü gyermekek fejlődésére (Kézdi és Surányi, 2008). A szerbiai inkluzív pedagógia a sajátos oktatási, nevelési igényü tanulóknál nem foglalkozik kellő alapossággal az eltérö hátterü tanulók együttnevelésével, holott Forray és Hegedüs (1998) szerint a cigány családok és az iskola közti feszültség egyik fő forrása a nevelési célokról, nevelési feladatok megosztásáról való eltérő vélekedés lehet. Az oktatási intézmények úgy tartják, a sikeres nevelés és oktatás egyik alappillére, ha a szülők együttmüködnek az adott intézménnyel, hogy a pedagógus mind jobban folytatni tudja azt a nevelési stratégiát, amit a szülő otthon elkezdett, felmérje időközben a családi hátteret, és felmérések után a pedagógus jobban tud igazodni a gyerekhez, könnyebben megérti az esetlegesen felmerülő, iskolában/óvodában kialakult problémák okát, és orvosolni tudja azt. A roma családok ezzel ellentétben sok esetben nem mutatnak nagy támogatást és együttmüködést, ami elengedhetetlen a sikeres nevelés és oktatás végrehajtásához, inkább úgy 
tartják, az iskola arra való, hogy az alapkészségeket, mint az írás, olvasás és számolás megtanítsák a gyerekeknek.

A szociális-emocionális területen mutatkozó eltérések részben okai, részben következményei is lehetnek a tanulási problémáknak. Pap (2010) szerint zavarok mutatkozhatnak:

- a késztetések területén (apátia, passzivitás, túlérzékenység, hiperaktivitás),

- az általános pszichés állapotban (levertség, féktelenség, szorongás),

- a motiváció alakulásában (motiválatlanság, megközelíthetetlenség),

- a munkavégzésben (gyors kifáradás, vontatott tempó, impulzivitás),

- az önirányításban (rövid zárlati cselekvések, labilitás),

- az önértékelésben (kisebbségi érzés, hiányos énkép, túlzott elbizakodottság, egocentrizmus)

- és a szociális beilleszkedésben.

A romák munkaerő-piaci elhelyezkedési lehetőségei nehezek, ezt tovább nehezíti a szociális kompetenciák hiánya. A romák munkaerő-piaci sikertelenségének egyik legfontosabb oka a modern kapitalista gazdaságban szükséges készségek nagymértékü hiánya. Ezen készségek kialakulásának pedig egyik legfontosabb színtere az iskola. Ezért logikus a következtetés, hogy a roma kisebbség hosszú távú sikerességének fontos tényezője az oktatás. A legújabb munkaerő-piaci kutatások kimutatják, hogy az úgynevezett „kognitív” készségek és kompetenciák (pl. számolási készségek, szövegértés) mellett a pozitív önértékelés, a sorsirányítás képességének érzése vagy a nehéz helyzetekkel való megküzdés készsége ugyanolyan fontosak a munkaerő-piaci sikerhez (Kézdi és Surányi, 2008).

Nagy József szerint a szociális kompetenciának vannak öröklött és tanult komponensei. A szociális kompetencia kialakulását befolyásoló tényezőknek a következőket tekinti: az egyén személyisége, a család és az iskolai környezet. Tehát, ha a szociális viselkedésnek vannak tanulható elemei, akkor tanítható is, ha megfelelö tanulási tapasztalatokat szerezhetnek a gyerekek. Mivel a szocializáció egyik helyszíne az iskola, az oktatásban részt vevőknek meghatározó szerepük van a hatékony szocializációs folyamatok irányításában. A szocializáció tanulható és tanítható folyamat, a szociális képességek és készségek fejlesztése minden tanuló érdeke, a társadalomnak pedig természetes elvárása (Radnóti, 2005). A szociálisan sikeres gyerekeknek több lehetséges technikájuk létezik a mindennapi interperszonális helyzetek kezelésére. Ezek magukban foglalják a várható problémák kialakulása iránti fogékonyságot, az alternatív cselekvési lehetőségek elgondolását, továbbá a cselekvések következményei, ill. a viselkedésben megmutatkozó ok-okozati hatás iránti érzékenységet (Nagy, 2003). A szociális kompetencia fejlődése lényegét tekintve a szociális komponenskészletek gyarapodása (vagyis szokások, minták, attitűdök, meggyőződések, készségek, ismeretek sokaságának elsajátítása), az egyéni szociális értékrend erősödése, a kreativitás növekedése révén valósul meg (Szegál, 2007).

Az inklúziós törekvések ellenére a hátrányos helyzetü tanulók átlagon aluli kognitív és szociális készségek és képességek birtokában csak pár éven keresztül maradnak a többségi általános iskolában, a pedagógusok ajánlására (amint a szülő engedélyezi és a szakszolgálat elfogadja a javaslatot) átkerülhetnek a szegregációs oktatásba, a speciális tagozatra, kisegítő iskolába. Feltételezésünk szerint, ha a hátrányos helyzetű tanulók szociális kompetenciáit sikerülne egy meghatározott szintig fejleszteni, nem kerülnének át speciális tagozatra, talán átlagon aluli eredménnyel, de befejezhetnék az általános iskolai oktatást normál tagozaton. Erre a problémára kerestünk egy hosszú távon is fenntartható megoldást.

\section{A hallgatói mentorprogram bemutatása}

A vajdasági Kanizsa Község túlnyomórészt magyarok lakta településének egyik jelentős problémája volt a Horgosi Október 10. Általános Iskola roma tanulóinak oktatása és nevelése. 
A gyakorló pedagógusok kétségbeesett beszámolói szerint a 2010-ben meghozott új oktatási törvény szerinti együttnevelés rengeteg problémával járt, a nem roma és a roma tanulók oktatásában egyaránt. Az iskola nem volt felkészülve a tömegesen beiskolázott roma gyerekek szocializációs nehézségeinek kezelésére, és ez egyre nagyobb problémát jelent a településen. A 2013/2014-es tanévben a Motiváció Hallgatói Mentorprogram az EDUCOOPprojekt (Educational Cooperation for Disadvantaged Children and Adults) részeként, az IPA Magyarország-Szerbia Határon Átnyúló Együttmüködési Program keretein belül valósult meg, a Szegedi Tudományegyetem Felnőttképzési Intézetének és az Újvidéki Egyetem Magyar Tanítási Nyelvü Tanítóképző Karának együttműködésében, a Motiváció Oktatási Egyesület szakembereinek közremüködésével. A 2013/2014-es tanévben mind Szegeden, mind Szabadkán 15 felsőoktatási hallgató mentorált 45-45 hátrányos helyzetủ általános iskolás diákot. A mentorprogram magyar oldalon három szegedi általános iskolában, szerb oldalon egy intézményben, a horgosi általános iskolában müködött.

A Hallgatói Mentorprogram célja, hogy intenzív kulturális, oktatási és kutatási együttmüködés alakuljon ki a partnerek között, valamint, hogy a hátrányos helyzetủ és roma származású gyerekek szociális és tanulmányi integrációjának támogatására megfelelő szakmai háttér alakuljon ki a tervezett tevékenységek által (Takács, 2014).

Az Újvidéki Egyetem szabadkai Magyar Tannyelvü Kara (MTTK) és a Felnőttképzési Intézet között fennálló, hosszú évek óta tartó gyümölcsöző együttmüködés eredményeképpen merült fel a mentorprogram kiterjesztésének lehetősége a Vajdaságban is. Ehhez nemcsak az MTTK oktatóinak és hallgatóinak bevonására volt szükség, hanem egy állandó gyakorlóhelyszín kiválasztására is, mégpedig úgy, hogy az egy olyan együttmüködő iskola legyen, amelyben a hátrányos helyzetü tanulók felzárkóztatására nagy az igény. Az MTTK hallgatói a térség különböző településeiről érkeznek, ezért az oktatók tájékozódhatnak a helyi viszonylatokban tapasztalható gondokról. Nagyon sok olyan körzet van, ahol nemcsak egyéni, hanem akár egész tagozatokra vagy iskolákra jellemző a hátrányos helyzetü gyerekek jelenléte. Feltérképezve a helyzetet a horgosi Október 10. Általános Iskolára esett a választás, amely földrajzilag Szeged és Szabadka között félúton helyezkedik el. Nagyszámú, szociális helyzetükből adódóan hátrányos helyzetü, illetve roma diákkal dolgoznak, és a mindennapjaik része a velük való külön foglalkozás. Már korábban is sokat tettek a gyerekek és az érintett családok érdekében, de a módszertanilag megalapozott mentorprogramban való részvétel lehetöségét különösen fontosnak érezték. Az iskola igazgatója és az érintett pedagógusok pontos és értékes adatokkal szolgáltak a projekt előkészítésekor, a megvalósítás ideje alatt pedig mindent elkövettek annak érdekében, hogy a diákokkal történő foglalkozások zökkenőmentesek legyenek. Az MTTK mentorhallgatóinak, akik a szegedi tapasztalatok alapján, szakmai felkészítés mellett végezték a felzárkóztató munkát, emberileg, módszertanilag is sokat segítettek. A program vajdasági, illetve horgosi alkalmazását kutatások kísérték, adaptálásának eredményeit felmérések igazolják, amelyekhez ugyancsak szükség volt az Október 10. Általános Iskola pedagógusainak segítéségére.

\section{A mentorpogram megvalósítása}

A mentorprogramnak három alappillére volt. Az első ezek közül maga a képzés és a képzési anyag kidolgozása. Öt tanítóképzős tantervbe integrált tantárgyat vehettek fel hallgatóink. Ezek voltak a Hátrányos helyzetü tanulók integrációja, oktatási problémáinak kezelése, Innovatív oktatási megoldások, Motiváció a hátrányos helyzetü tanulók körében, Felnőttképzés a hátrányos helyzetü csoportok körében, A nyelvi hátrányos helyzettől az analfabetizmusig.

A második volt maga a hallgatói mentorprogram, amely leegyszerüsítve abból állt, hogy egy mentorhallgató három mentortanulóval foglalkozik a tanév során. Ez a foglalkozás 
magában foglal korrekciós, prevenciós, tanulmányi felkészítést, fejlesztést, szabadidős programokat, és többek között még a szociális kompetenciák erösítését is. A 45 tanuló egyéni oktatási terv szerint tanult.

A harmadik alappillér pedig a kutatás volt. A program ideje alatt három kutatási területet öleltek fel a felmérések és azok kiértékelései: a közösen kidolgozott képzési anyagok hatékonyságának vizsgálata hallgatói kérdőívek és fókuszcsoportos beszélgetések segítségével; a Mentorprogram eredményének, a mentorok tapasztalatainak vizsgálata interjúk segítségével; a Mentorprogram fenntarthatósági és disszeminációs stratégiájának kidolgozása. Valamint elkészült egy tanulmánykötet is A szabadkai-horgosi mentorprogram tapasztalatai címmel. Ezen kötetben 126 horgosi hátrányos helyzetü és átlagos társadalmi státuszú kisiskolás kognitív, szociális, emocionális és fizikai teljesítményét vizsgáltuk, különböző mérőskálák segítségével.

2013. májustól augusztusig történt a tananyagok kidolgozása, szerbiai adaptálása. Július elején szerveztük meg a mentorok felvételi beszélgetését, ahol 30 hallgatót hallgattunk meg, és ebböl került ki 15 ösztöndíjas hallgató és 3 önkéntes hallgató. A mentorok kiválasztása egy kétlépcsős folyamat során történt. A jelentkezőknek először önéletrajzot és motivációs levelet kellett benyújtaniuk. A program követelményeinek megfelelően kialakított önéletrajzsablon a mentori munka szempontjából hasznos elméleti és gyakorlati tudás, valamint előzetes tapasztalatok felmérését célozta. A dokumentumok benyújtását követően egy felvételi beszélgetésre került sor, ahol a jelentkező rátermettségét, előzetes tapasztalatait, emellett a roma és a hátrányos helyzetü csoportok iránti attitüdjét tárták fel a programot koordinálók (Fejes, Kelemen és Szücs, 2014).

Szeptembertől indult a gyakorlati munka, a hallgatóknak egyszerre kellett megküzdeni az iskolai valóságsokkal és az önképzésükkel is, hiszen a kurzusok is akkor indultak el. Az iskolai munka kedden és pénteken valósult meg. Az öt kurzusból három az első szemeszterben került megszervezésre, a másodikban kettőt hallgathattak le hallgatóink. Szeptemberben csapatépítő tréninget szerveztünk a mentoroknak. A félév során hallgatóink részt vettek az iskolanapon, karácsonyi készülődésekben, szabadidős programokban, kirándulásokon. Többnyire csak kezdeti problémák voltak a pedagógiai munkával kapcsolatban. Sok kérdés és kétség fogalmazódott meg a mentorokban, amelyeket hamar sikerült megválaszolni, ilyen volt például, hogy milyen fajta pedagógiai munkát kell végezni, mennyire lehet befolyásolni a kisdiákok szociális kompetenciáit, mennyire lehet beleszólni az iskolai életbe. Nagy segítséget jelentett az általános iskolás gyakorló tanítók konstruktív munkája, valamint a közös fórumokon, megbeszéléseken megvitatott problémák, egymás tapasztalatainak meghallgatása, lehetőségek mérlegelése.

Két hallgatói csereprogramot szerveztünk, ahol találkozhattak a mentorok és ötleteket oszthattak meg egymással Szegeden és Szabadkán is. Júliusban pedig két gyereknapot is tartottunk, szintén mindkét városban, az összes mentorált tanulóval és mentorral együtt. Záró konferenciánkra június 27-én Szabadkán került sor. Fontos tapasztalatnak mondhatjuk, hogy egy gyakorlati oktatást kaptak a hallgatóink, amely egy lényeges szempont volt a program megvalósítása kapcsán.

\section{A mentortorok véleménye}

A következőkben Losonc Szintia, Januskó Izolda és Valkovics Melinda mentorok összefoglalóját mutatjuk be a mentorprogramban vállalt szerepükről: „2013 májusában hallottunk először a programról, akkor még nem tudtunk, mit jelent. Júniusban volt egy nyitókonferencia, ahova el lehetett látogatni, de semmilyen kötelezettséget nem jelentett. Ott betekintést nyertünk a mentorprogramba, hogyan dolgoznak, mik a céljaik, jó gyakorlatok bemutatása, és milyen nehézségekkel kell megküzdeni egy mentornak. Szeptemberben 
mentünk el először Horgosra, és az első hónap a kapcsolat kialakításáról szólt, vagyis az ismerkedésről. Lassan kialakult minden, tisztában lettünk azzal, hogy mit és hogyan kell megtanítani a gyerekeknek. Olyan tudást kaptunk a kurzusokon, amit fel tudtunk használni az iskolában. A tanulókat elsősorban matematikából és magyar nyelvből próbáljuk felzárkóztatni, de nagy szükségét láttuk a hátrányos helyzetükből adódó hiányzó szocializációs képességek pótlásának. Minden mentornak megvan a maga módszere a motiválásra. Ha nincs kedvük olvasni, játékkal tudjuk őket motiválni.

Mindenkinek vannak pozitív és negatív élményei a mentorprogrammal kapcsolatban, de az utóbbi leginkább csak a kezdeti nehézségekre kapcsolatos. Mindenki szép élményekkel fogja zárni ezt a programot, de én a legszívesebben arra gondolok vissza, hogy a gyerekek és a tanító is gyorsan befogadtak az osztályközösségbe. A céljaink is eltérőek, mert aki olyan osztályban van, ahol elsős gyerekekkel foglalkozik, neki az a fontos, hogy a többiekkel tudjon haladni, aki pedig negyedikessel, neki az a célja, hogy megtanítsa írni-olvasni.

Egy kis közösséget kovácsoltunk már össze, szabadidős tevékenységeket is szervezünk, nagyon sok kisgyerek nem is látott még mesét, és ezekre is szakítunk időt. Amellett, hogy a nyelvi és matematikai képességeket alapozzuk, szakítunk időt a képzőmüvészeti és zenei nevelésre is. Többnyire ezek a gyerekek kiszakadnak az osztályból, sokszor csúfolják öket, és kiközösíti őket az osztály. A mentorhallgató egy pótanyuka, barát szerepét vette fel, akihez jó ragaszkodni, és ha a gyermek bizalmába tud férkőzni a mentor, mindent el tud érni nála. A mentorok közötti együttmüködés is nagyon szépen kialakult, minden eszközt és játékot, amit elkészítettünk, továbbadjuk, hogy a többi mentor is felhasználja. Az én hallgatóim között van olyan kislány, aki az iskolában nem szólal meg, nem kéredzkedik ki az illemhelyre sem, a tanítónővel, osztálytársaival egyáltalán nem kommunikál. Nála elértem azt, hogy velem baráti szinten teljesen jól beszél, mindent elmond. Most már a barátaival is kezd beszélgetni, és remélem, júliusban már arról számolhatok be, hogy teljesen feloldódott.

Úgy érzem, hogy van értelme annak, amit csinálunk, és nagyon büszke vagyok rá, hogy részese lehettem a mentorprogramnak. Az eredményeinket nem tudjuk számbelileg kimutatni, de a tanítók visszajelzése az, amiböl eröt és motivációt gyüjthetünk. Nagyon fontosnak tartom elmondani azt, hogy az egyetemi tanárainkkal és a horgosi iskola dolgozóival is nagyon jó a kapcsolatunk, és ez az együttmüködés nagyban hozzájárul a sikerhez."

\section{A mentorált tanulók szociális kompetenciáinak fejlődése}

Mivel a Hallgatói Mentorprogram a mentorált tanulók fejlődését több oldalról kívánja támogatni, mint pl. a mentorált tanulók tanulmányainak felzárkóztatása, a szociális integráció segítése, a tanulók személyes és szociális kompetenciáinak fejlesztése (Kelemen, Szücs, Fejes, Németh és Csempesz, 2013), sok esetben rendkívül nehéz meghatározni azt a célt, amelynek elérése az adott mentorált tanuló kapcsán rövid távon kitüzhető. A hátrányok általában komplexen, és egymásra is hatva jelentkeznek, ami még inkább megnehezíti a célok kitüzését (Józsa és Fejes, 2010). A projektum szabadkai oldalánál érzékelhetően nagyobb hangsúlyt kapott az oktatást segítő, azt kiegészítő tevékenységek mellett a szociális beilleszkedés támogatása, integrált szabadidős programok szervezése. Félig strukturált interjú segítségével vizsgáltuk a horgosi mentorprogramban részt vevő gyakorló pedagógusok tapasztalatait a mentorált tanulók szociális kompetenciáinak tartós javulását tekintve. Több pedagógus arról számolt be, hogy a program lefolyása utáni évben volt leginkább érezhető és kimutatható a hatás, akkor, amikor egyedül maradt a mentorált gyerekekkel. A tanulók képesek voltak az önálló szociális integrációra, egyedül dolgoztak, elvégezték a kiosztott feladatokat, és az osztályközösség befogadóbb, elfogadóbb 
magatartást tanúsított irányukba. Az az első osztályos gyermek, aki a mentorprogram alatt egyéni fejlesztési tervvel tudott haladni, 3. osztályra már az átlag tanulók közé tartozik. Azzal a segítséggel, hogy különleges bánásmódban részesültek egy teljes tanéven keresztül a mentorok által, az alap kognitív kompetenciákban felzárkóztak, és a társas viselkedésekben is észrevétlenül beilleszkedtek az többi tanuló közé. Az interjúk során megkérdeztük, hogy a pedagógusok miben látják a megoldást: „Így, ahogy itt megtörtént, meg kellene ismételni a mentorprogramot, és nem azon kell gondolkodni, hogy legyen-e folytatás, hanem, hogy hogyan legyen!"

Egy másik pedagógus elmondása szerint: „...sajnos még mindig van olyan gyerek, aki nem beszél, zárkózott, idő kellene, és egy támogató barát (mentor), akit közel tudna engedni magához". Az érzelmi kompetencia fejlődésében - akárcsak a szociális kompetencia esetében - a biológiai alapprogramok és a környezeti tényezők egyaránt nagyon fontos szerepet játszanak (Saarni, 1999). A gyerekek érzelmeire és viselkedésére adott szülői és tanári válaszok hatásának azonosítása szintén számos pedagógiai probléma megoldását segíthetné. Külföldi kutatások egyértelmüen bizonyítják, hogy az iskolai évek alatt a pedagógusnak igen fontos szerepe van a szociális és az érzelmi kompetencia fejlödésében (Zsolnai és Kasik, 2007). Egy pedagógus véleménye alapján: „...a hátrányos helyzetü gyerekek leginkább magukat különítik el, még akkor is, ha az osztály befogadó lenne. Tud olvasni, szépen megtanult, de suttog. Nagyon gátlásos. Nagyon fontos a kapcsolati tőke, ők azok, akik ölelnek, szeretnek, puszilnak..."

\section{A jövőbeli tervek, lehetőségek}

A Hallgatói Mentorprogram elsődleges célja a hátrányos helyzetü tanulók tanulmányi felzárkózásának és szociális integrációjának segítése volt, de közvetett módon a pedagógusjelöltek szakmai felkészítésének támogatása és a társadalmi érzékenyítés elősegítése is a célkitüzések között szerepelt (Szücs és Fejes, 2010). A mentorprogram koordinátora is elmondta, hogy minden utat megpróbált megmozgatni, mert annyira jónak ítélte meg a programot, keresik a lehetőségeket. A mentorprogram megvalósítható lenne, akár másik falusi általános iskolában is, csak a mentorok útiköltsége, bérezése a pénzügyi probléma, amit le kellene győzni. A tanítóképző karon folyó pedagógus-továbbképzések alkalmával a gyakorló tanítók elmondása szerint nagyon nagy igény lenne a pedagógusi asszisztens bekapcsolására, még akkor is, ha egy gyakorlati tapasztalatokkal nem rendelkező hallgató személyében történne. Diákjaink szakmai gyakorlatot szereznek, a pedagógusok, pedig ezáltal nagy segítséget kapnának. Abból a szempontból nehezen követhető a szociális kompetencia változása, hogy ezek a gyerekek mára már a felső tagozatos tanárok irányítása alá kerültek, akik viszont nem látták őket az előzőekben, nem ismerik a bemenő szociális kompetenciájukat.

Fontos megállapítás a részünkröl, hogy amint sikerül a programot újra életre kelteni, mérni fogjuk a tanulók bemenő és kimenő alap- és szociális kompetenciáit, hogy pontos statisztikai adatokkal tudjuk alátámasztani a jó gyakorlatunk sikerességét.

\section{Irodalom}

Fejes J. B., Kelemen V. és Szűcs N. (2014). A Motiváció Hallgatói Mentorprogram Modellje - Útmutató felsőoktatási hallgatók részvételével szervezett hátránykompenzáló programok megvalósításához. Szeged. Letöltés: 2015.október 7.; Web: http://www.staff.uszeged.hu/ fejesj/pdf/FJB_KV_SZN_mentorprogram_ekonyv_hu.pdf 
Forray R. K. és Hegedüs T. A. (1998). Cigány gyermekek szocializációja. Család és iskola. Aula Kiadó Kft., Budapest.

Józsa K. és Fejes J. B. (2010). A szociális környezet szerepe a tanulási motiváció alakulásában: a család, az iskola és a kultúra hatása. In Zsolnai A. és Kasik L. (szerk.): A szociális kompetencia fejlesztésének elméleti és gyakorlati alapjai. Tankönyvkiadó, Budapest. 134-162.

Kalocsainé S. H. és Varga A. (2005). Az iskola mint társadalmi és oktatási idea. Educatio, 1. sz. 204-208.

Kelemen V., Szücs N., Fejes J. B., Németh K. és Csempesz P. (2013). A Hallgatói Mentorprogram. In Fejes J. B. és Szücs N. (szerk.): A szegedi és hódmezővásárhelyi deszegregációt támogató Hallgatói Mentorprogram. Öt év tapasztalatai. Belvedere Meridionale, Szeged. 107-127.

Kézdi G. és Surányi É. (2008). Egy sikeres iskolai integrációs program tapasztalatai. Kutatási összefoglaló. Educatio Társadalmi Szolgáltató Közhasznú Társaság, Budapest. Letöltés: 2015. október 6.; Web: http://old.wekerle.gov.hu/download.php?doc_id=2072.

Lepes, J., Csapó M., Bagány Á. és Grabovác B. (2014). A szabadkai-horgosi mentorprogram tapasztalatai. Grafoprodukt, Szabadka.

Nagy, J. (2003). Szociális kompetencia és proszocilaitás. In Zsolnai A. (Szerk.): Szociális kompetencia - társas viselkedés. Gondolat Kiadó. Budapest. 2003. 120-137.

Papp G. (2010). A tanulásban akadályozott tanulók és az olvasás. Könyv és Nevelés. XII. évfolyam, 2010/01 szám, Olvasáspedagógia rovat.

Radnóti, K. (2005). A szociális kompetencia fejlesztési lehetőségei a mai magyar iskolában a tanórákon. In Kerber Z. (Szerk.) Hidak a tantárgyak között. Országos Közoktatási Intézet, Budapest. 105-120.

Saarni, C. (1999): The Development of Emotional Competence. Guilford Press, New York.

Szegál, B. (2007). A sajátos nevelési igényü és hátrányos helyzetü tanulók integrált oktatásának és nevelésének megalapozása. In Girasek J. (szerk.): Inkluzív nevelés - A tanulók hatékony megismerése. SuliNova Közoktatás-fejlesztési és Pedagógustovábbképzési Kht., Budapest. 53-68.

Szücs N. és Fejes J. B. (2010): A deszegregációs intézkedéseket támogató Hallgatói Mentorprogram lehetőségei a pedagógusképzésben. In: Albert G. (szerk.): $A z$ óvodapedagógiától az andragógiáig. Kaposvári Egyetem Pedagógiai Kara, Kaposvár. 113125.

Takács M. (2014). Előszó. In A szabadkai-horgosi mentorprogram tapasztalatai. Grafoprodukt, Szabadka.

Törteli, Á. (2014). The Interpretation of Inclusive Education in Serbia. In Ambrusné Kéri K. (szerk.): Perspektívák a neveléstudományban. PTE BTK „Oktatás és Társadalom” Neveléstudományi Doktori Iskola, Pécs.

Zsolnai, A. és Kasik, L. (2007). Az érzelmek szerepe a szociális kompetencia müködésében, Új pedagógiai szemle 57. évf. 7-8. sz.. július/augusztus. Letöltve: 2015. október 06.; Web: http://epa.oszk.hu/00000/00035/00115/2007-07-ta-Tobbek-Erzelmek.html 